\title{
KONGLOMERASI MEDIA DAN POLITIK: ANALISIS KOMODIFIKASI TV SATELIT BERLANGGANAN INDOVISION DALAM PESTA DEMOKRASI
}

\author{
Rivga Agusta \\ Fakultas Ekonomi dan Sosial, Universitas AMIKOM Yogyakarta \\ Email: rivgagusta@ amikom.ac.id
}

\begin{abstract}
Media ownership is closely related to political-economic interests. Whether it involves power over the economic industry that encompasses its fields, as well as power in the political sphere. Ownership of subscription satellite TV also has its own advantages in the sphere of media-political economy. In the momentum of the 2014 legislative and presidential elections, subscription satellite TV Indovision as a subsidiary of broadcast media owned by Harry Tanoesodibjo has its own role. In this article, Indovision's role in the democratic party was analyzed by looking at the theory of commodification of audiences and the commodification of content, both of which are interrelated in perfecting the commodification of political advertising content in Indovision subscription TV. The analysis was carried out using a qualitative descriptive research method with the presentation of several points, including Indovision Domination in the Subscribed Satellite TV Market; Indovision Commodification (covering commodification of audiences and content); and Commodification of Political Advertising Content.
\end{abstract}

Keywords: Political Economy of Media, TV Cable, Content Commocification, Audiens Commodification.

\section{A. PENDAHULUAN}

Televisi berlangganan merupakan jasa penyiaran saluran televisi yang disajikan khusus untuk khalayak penonton yang bersedia membayar atau berlangganan secara berkala. Pada umumnya, jasa ini disediakan dengan menggunakan sistem digital ataupun analog melalui media satelit. Saat ini sistem penyiaran dengan digital merupakan sistem yang paling sering digunakan.

TV berlangganan banyak ditawarkan dengan sistem pay per view atau PPV dengan menggunakan kabel ataupun satelit penyiaran langsung (Direct Broadcast Satellite (DBS)). Dengan penggunaan sistem ini, para pengguna TV berlangganan harus menunggu sampai program siaran yang diinginkan dapat ditayangkan dengan baik oleh kabel maupun DBS. ${ }^{1}$

Di Indonesia, TV berlangganan semakin berkembang melihat munculnya beberapa perusahaan TV berlangganan seperti Indovision, Oke Vision, Aora, NexMedia, Telkom Vision, dan masih banyak lagi. Indovision merupakan salah satu TV berlangganan yang cukup populer di kalangan masyarakat Indonesia yang juga dikenal sebagai televisi berlangganan yang pertama kali menggunakan DBS. Indovision sendiri merupakan perusahaan TV berlangganan yang berada di bawah PT MNC Sky Vision.

\footnotetext{
${ }^{1}$ Terarsip dalam http://www.dgspeak.com/teknologi/berkenalan-dengan-tv-berlangganan/diakses pada 28 April 2014 pukul 12.03 WIB
} 
PT MNC Sky Vision sebelumnya telah memiliki stasiun televisi lokal yakni RCTI, MNCTV, dan GlobalTV. Adanya TV satelit berlangganan Indovision membuat semakin melebarnya rentangan sayap perusahaan media milik Harry Tanoesodibjo ini. Keberadaan media sendiri merupakan salah satu hal yang sangat menguntungkan dalam momen pemilihan legislatif dan pemilihan presiden tahun 2014 ini. Sehingga pada artikel ini, penulis tertarik untuk mengulas bagaimana TV berlangganan diberdayakan oleh sang pemilik media untuk memenuhi kepentingan politiknya.

Kepemilikan media erat kaitannya dengan kepentingan ekonomi-politik. Baik itu yang melibatkan kekuasaan atas industri ekonomi yang melingkupi bidangnya, maupun kekuasaan di lingkup politik. Analisis mengenai pemberdayaan TV berlangganan bertujuan untuk melihat bagaimana modal yang dimiliki TV berlangganan Indovision diberdayakan oleh sang pemilik untuk memenuhi tujuannya dalam momentum pemilihan legislatif dan pemilihan presiden 2014. Pemberdayaan TV berlangganan Indovision sendiri akan diulas melalui pintu masuk komodifikasi khalayak dan komodifikasi konten yang keduanya saling berkaitan dalam menyempurnakan komodifikasi konten iklan politik di dalam TV berlangganan Indovision. Untuk menganalisis hal tersebut, penulis akan menjabarkan dalam beberapa poin antara lain penjelasan mengenai dominasi Indovision di Pasar TV Satelit Berlangganan; Komodifikasi Indovision (meliputi komodifikasi khalayak dan konten); dan Komodifikasi Konten Iklan Politik.

\section{B. METODOLOGI}

Data dan analisis dalam kajian ini diperoleh dengan metode penelitian deskriptif kualitatif. Penelitian kualitatif dipilih karena penelitian ini merupakan penelitian yang menekankan makna daripada generalisasi dan instrumen kunci dalam penelitiannya adalah peneliti itu sendiri. ${ }^{2}$ Dengan penelitian deskriptif kualitatif, fenomena-fenomena dideskripsikan dan digambarkan dengan mengacu pada karakteristik, kualitas, dan keterkaitan antar kegiatan. ${ }^{3}$ Dengan metode deskriptif kualitatif, data yang didapatkan merupakan gambaran suatu kondisi yang apa adanya karena tidak ada pemberian perlakuan, manipulasi atau pengubahan pada variabel-variabel yang diteliti. Sehingga metode ini dirasa tepat untuk mengeksplorasi fenomena komodifikasi konten dan komodifikasi khalayak yang dilakukan TV satelit berlangganan Indovision dalam momentum pemilihan legislatif dan pemilihan presiden tahun 2014.

\section{HASIL DAN PEMBAHASAN}

\section{Dominasi Indovision di Pasar TV Satelit Berlangganan}

Indovision adalah sebuah stasiun televisi satelit berlangganan yang berdiri di bawah PT. MNC Sky Vision/ MSV (dahulu bernama PT Matahari Lintas Cakrawala). PT MNC Sky Vision

\footnotetext{
${ }^{2}$ Sugiyono. 2012. Metode Penelitian Kuantitatif, Kualitatif dan R \& D. Bandung: Alfabeta. Hal. 9

${ }^{3}$ Sukmadinata, Nana Syaodih. 2011. Metode Penelitian Pendidikan. Bandung: PT Remaja Rosdakarya. Hal. 73
} 
sendiri adalah pelopor di industri televisi berbayar satelit di Indonesia. Perusahaan yang didirikan pada tanggal 8 Agustus 1988 ini memulai memasarkan produk jasanya pada awal tahun 1994 dan bertanggung jawab atas pemasaran program pengelolaan serta pelayanan kepada pelanggan. ${ }^{4}$

Awalnya Indovision menggunakan jasa satelit Palapa C-2 untuk menggunakan transponder dan sistem broadcasting serta menggunakan analog dengan frekuensi C-Band. ${ }^{5}$ Namun, pada bulan Mei 2009, MSV meluncurkan satelit Indostar-II (SES 7) karena masa orbit satelit Indostar I yang sudah habis, dan menggantikan posisi satelit Indostar-I . Mengudara pada frekuensi yang sama dari Sband, satelit Indostar-II memiliki 10 transponder S-Band dengan teknology lebih modern dibandingkan dengan Indostar-I, yang memungkinkan penambahan channel yang lebih banyak dibanding satelit sebelumnya dan juga penambahan beberapa channel berkualitas HD (High Difinition). Frekuensi S-Band yang lebih tahan terhadap perubahan cuaca, sesuai dengan keadaan daerah tropis pada umumnya serta memiliki jejak jangkauan ke seluruh wilayah Indonesia. ${ }^{6}$

TV berlangganan mendapat respon yang cukup positif dari masyarakat Indonesia seiring dengan perkembangan ekonomi dan sosial masyarakatnya. Di Indonesia, TV berlangganan Indovision merupakan TV berlangganan yang cukup populer. PT MNC Sky Vision mencatat pertumbuhan bisnis selama April 2013, operator televisi berbayarnya yang mengusung merek Indovision, Top TV, dan Okevision mengantongi pendapatan Rp 244 miliar, atau meningkat 33,33\% year-onyear (YoY).

Pencapaian ini ditopang oleh pertumbuhan jumlah pelanggan. Pada akhir tahun 2012 MNC Sky Vision mampu menggaet sebanyak 1,72 juta pelanggan. Per akhir April tahun 2013, pelanggannya sudah mencapai 1,92 juta. Manajemen Sky Vision memproyeksikan pendapatan hingga akhir 2013 mencapai Rp 3,2 triliun dengan EBITDA Rp 1,34 triliun. ${ }^{7}$

Produk PT MNC Sky Vision ini menguasai $73 \%$ pangsa pasar TV berlangganan dengan kurang lebih 50.000 pelanggan baru setiap bulannya ${ }^{8}$. Tingginya konsumen TV berlangganan menunjukkan mulai adanya pergeseran budaya menonton TV di Indonesia yang mulai cenderung mengonsumsi tayangan TV berlangganan.

\section{Komodifikasi Indovision}

Komodifikasi menjadi salah satu pintu masuk dalam menganalisis pemberdayaan TV berlangganan Indovision. Komodifikasi sendiri merupakan transformasi obyek dan layanan ke dalam komoditas.

\footnotetext{
${ }^{4}$ Aditya Wahyu Pribadi. 2012. Analisis Strategi Bersaing Dalam Rangka Kompetisi Industri TV Berlangganan (Studi Kasus: PT. Mediatama Anugrah Citra). Tesis Fakultas Teknik Magister Manajemen Telekomunikasi. Jakarta: Universitas Indonesia. Hal. 29

${ }^{5}$ Ibid

${ }^{6}$ Terarsip dalam http://www.infotelevisi.com/1/tv-berlangganan-Indovision/ diakses pada 9 Juli 2014 pukul 10.00 WIB

${ }^{7}$ Terarsip dalam http://industri.kontan.co.id/news/indovision-menggenggam-192-juta-pelanggan diakses pada 28 April 2014 pukul 12.01 WIB

${ }^{8}$ Terarsip dalam http://www.beritasatu.com/emiten/115230-perkuat-pasar-mnc-sky-raih-186-jutapelanggan.html diakses pada 28 April 2014 pukul 12.17 WIB
} 
Komodifikasi lebih menekankan pada proses daripada indutrialisasi. Pada level dasar, hal ini melibatkan produksi tidak hanya untuk digunakan tapi juga sebagai alat pertukaran (exchange). ${ }^{9}$ Menurut Mosco, komodifikasi adalah proses transformasi nilai guna menjadi nilai tukar. ${ }^{10}$ Konsep komodifikasi Mosco meliputi komodifikasi konten, khalayak, dan pekerja. Komodifikasi konten adalah proses perubahanpesan dari sekumpulan data kepada sitem makna dalam bentuk produk yang dapat diterima oleh pasar. Komodifikasi khalayak adalah proses modifikasi peran audiens oleh media kepada pengiklan, yang mana fungsi awalnya sebagai konsumen media menjadi konsumen non media. Sedangkan komodifikasi pekerja adalah proses transformasi pekerja media melalui pemanfaatan sumber daya pekerja di dalam institusi media. Sedangkan pemberdayaan TV berlangganan Indovision memproses modal yang mereka miliki dalam komodifikasi khalayak dan konten.

a. Komodifikasi Khalayak Indovision

Profit utama Indovision berasal dari pay-per-view penonton. Sehingga berbagai channel dalam Indovision dihadirkan untuk menembus berbagai segmentasi masyarakat penonton. Sehingga sudah menjadi suatu kepastian jika Indovision melakukan komodifikasi khalayak.

Salah satu keunggulan yang ditawarkan TV berlangganan Indovision, khalayak dapat memesan acara sesuai dengan jadwal siarnya. Pada layar TV berlangganan, akan ditampilkan jadwal acara selama kurang lebih seminggu berikut dengan jam tayang serta narasi dari acara tersebut. Pada layar juga disediakan pilihan untuk memesan acara yang ingin ditonton pada waktu-waktu yang diinginkan. Pelayanan ini juga memudahkan khalayak jika melewatkan suatu acara favoritnya, karena acara-acara tersebut akan disiarkan ulang pada waktu tertentu yang sudah dijadwalkan.

Dalam memaksimalkan pelayanan kepada khalayak, Indovision juga selalu menayangkan iklan layanan yang hampir selalu ada di setiap channel seperti iklan pemasangan antena UHF untuk menonton tayangan khusus, layanan pemasangan decoder tambahan, perekaman acara yang diinginkan, dan tambahan masa berlangganan seperti dalam promo "Indovision Ajak-ajak". Khalayak merupakan komoditas utama Indovision sehingga Indovision pun tak segan-segan memaksimalkan pelayanannya.

b. Komodifikasi Konten Indovision

Motivasi utama khalayak untuk menggunakan TV berlangganan adalah dikarenakan TV berlangganan mampu menyediakan konten berkualitas. Jenis-jenis konten yang digemari antara lain yakni program anak dan keluarga, seperti film, hiburan, dan olahraga. Konten acara berbahasa asing juga menjadi populer ketika tersedianya terjemahan bahasa Indonesia. Channel-channel asing yang

\footnotetext{
${ }^{9}$ Hesmondhalgh (2007) dalam Sumantri Raharjo. 2011. Komodifikasi Budaya Lokal dalam Televisi (Studi Wacana Kritis Komodifikasi Pangkur Jenggleng TVRI Yogyakarta). Tesis Magister Program Studi Ilmu Komunikasi. Surakarta: Universitas Sebelas Maret. Hal.21

${ }^{10}$ Vincent Mosco. 2009. The Political Economy of Communication $2^{\text {nd }}$ Ed. London: SAGE Publication. Hal. 129
} 
menjadi favorit antara lain seperti AXN, BBC Knowledge, CBeebies, Disney, Fox, Star Worls, HBO, dan lainnya.

Di samping menghibur khalayak, Indovision tak lepas dari upaya-upaya pencapaian profit. Untuk itu Indovision secara maksimal melakukan komodifikasi konten. Komodifikasi konten merupakan proses komodifikasi di dalam komunikasi yang mengemas pesan-pesan menjadi sesuatu produk yang dapat diperjual-belikan. ${ }^{11}$ Supaya pesan tersebut dapat diperjual-belikan secara efektif, perusahaan berusaha menjadikan pesan yang dikomodifikasi menjadi suatu kebutuhan. Maka perusahaan menciptakan pesan-pesan yang dapat membentuk kesadaran masyarakat. Jika kesadaran masyarakat dapat dibentuk oleh media, sehingga masyarakat dapat dimanfaatkan oleh media.

Sebagai TV satelit berlangganan pertama di Indonesia, Indovision mampu menyediakan channel-channel TV interlokal yang tentunya tidak dapat disiarkan oleh TV antena parabola biasa. Indovision mengejar profit melalui komodifikasi konten dengan memberi masyarakat tayangan ratusan channel TV lokal maupun interlokal. Selain itu, Indovision memaksimalkan konten acara melalui channel milik MNC corp yang terdiri dari MNC Kids, MNC News, MNC Entertainment, MNC Lifestyle, MNC Shop, MNC Music, MNC Muslim, MNC Drama, MNC Fashion, MNC Infotainment, MNC Food \& Travel, MNC Movies, MNC Business, MNC Sports 1, MNC Sports 2, dan MNC Comedy. Channel MNC ini ada di setiap paket langganan Indovision, baik paket Super Galaxy, Galaxy, Venus, dan Mars.

\section{Komodifikasi Konten Iklan Politik Win-HT}

\section{a. Iklan Politik Partai Hanura}

Hasil dari upaya komodifikasi khalayak dan konten Indovision menjadi lahan potensial untuk menabur iklan politik sang pemilik yakni Harry Tanoesodibjo. Iklan politik sendiri secara singkat dideskripsikan sebagai penyiaran yang bersifat informastif dan persuasif dengan tujuan untuk meraih pemberi suara dan memberikan mereka pilihan politik yang meliputi partai politik, kandidat dan program. ${ }^{12}$ Kemudian, seperti kita ketahui bahwa Harry Tanoesodibjo mencalonkan diri sebagai wakil presiden dan berduet dengan Wiranto dalam naungan Partai Hanura.

Iklan partai Hanura sendiri sudah terkemas dalam tiga versi. Pertama, iklan Hanura dengan membawakan lagu "Sik-Asik" milik Ayu Ting-ting yang telah dimodifikasi liriknya. Pada iklan tersebut terdapat cuplikan beberapa lapisan masyarakat kalangan menengah ke bawah seperti petani dan pegawai pabrik yang menari-nari dengan diiringi lagu halauan untuk mencoblos No.10 yakni nomor dari Partai Hanura pada pemiu legislatif. Tak lupa di akhir iklan ditampilkan juga pasangan capres-cawapres dari partai tersebut.

\footnotetext{
${ }^{11}$ Ibid. Hal. 133.

12 Yunu Retnowati. 2013. Efektivitas Iklan dalam Meraih Prestasi Politik. Hal. 6. Terasip dalam http://www.academia.edu/5498153/EFEKTIVITAS_IKLAN_DALAM_MERAIH_PARTISIPASI_POLITIK
} 
Iklan kedua berfokus pada pasangan Wiranto dan Harry T. Di dalam iklan terdapat cuplikan beberapa orang dari kalangan petani khususnya dalam mengutarakan pendapatnya mengenai Win-HT. Iklan ketiga berisi cuplikan Win-HT yang berinteraksi dan terjun langsung ke tengah masyarakat, hingga beradegan menggendong anak-anak kecil.

b. Komodifikasi Konten dalam Spot Iklan Indovision

Tanpa adanya channel TV berlanggananan, dalam TV nasional pun Harry Tanosoedibjo sudah memasang lebih dari 10 spot iklan pemilu Partai Hanura di RCTI, MNC, dan Global TV setiap harinya. ${ }^{13}$ Menurut monitoring yang dilakukan perusahaan data mining Sigi Kaca Pariwara, pada periode masa kampanye terbuka iklan-iklan kampanye milik Partai Hanura menjadi yang paling aktif. Hasil monitoring menunjukkan berdasar jumlah frekuensi tayang pada periode 16 Maret 2014 pukul 00.00 WIB sampai dengn 5 April 2014 pukul 24.00 WIB, total jumlah tayangan iklan partai Hanura mencapai 2.489 kali tayang di televisi lokal. ${ }^{14}$

Iklan pemilu Partai Hanura juga ditayangkan di hampir semua channel MNC di TV berlangganan yang terhitung ada sebanyak 16 channel. Badan Pengawas Pemilu (Bawaslu) memberi peraturan bahwa batas tayangan iklan pemilu partai maksimum hanya 10 spot setiap harinya. Jika satu partai 10 spot dalam satu hari, bagaimana dengan partai dekengan Harry Tanoesodibjo di 3 channel TV nasional dan 16 channel TV berlangganan miliknya? Bisa lebih dari 100 spot tayangan setiap harinya.

Kendali atas isi media yang dilakukan MNC corp memang menjadi salah satu aktivitas pihak konglomerat dalam memanfaatkan media yang dimilikinya. Apalagi melalui kekuatan TV berlangganan Indovision dengan memaksimalkan komodifikasi konten dan penonton sehingga meraih 50.000 pelanggan setiap bulannya. Hal ini dapat dikatakan bahwa penonton membayar tak hanya untuk dapat menikmati konten yang diinginkannya, tetapi juga atas iklan pemilu partai.

Kendali konten media yang dapat dilakukan tidak hanya dalam media-media MNC saja, tapi jika kita kembali pada iklan layanan Indovision yang tayang di hampir semua channel TV di Indovision maka sangat berpotensi juga bagi pihak pemilik media untuk memasang iklan kampanye partainya di spot tersebut.

Indovision juga sempat kesempatan dengan mengganti tayangan, khususnya pada tayangan langsung sepak bola di channel tertentu seperti Indosiar dan SCTV. Hak siar pertandingan sepak bola tersebut memang ada pada Indosiar dan SCTV, sehingga tayangan tersebut tidak dapat disiarkan dalam channel Indosiar dan SCTV yang tayang dalam TV berlangganan Indovision. Karena peraturan itu lah, channel Indosiar dan SCTV yang tayang di bawah antena Indovision tidak menyiarkan apaapa. Pihak Indovision lalu menayangkan MNC Music dalam spot yang kosong di frekuensi Indosiar

\footnotetext{
${ }^{13}$ Terarsip dalam http://www.jpnn.com/read/2014/03/28/224951/Empat-Parpol-Langgar-Aturan-Iklan-di-TVdiakses pada 28 April 2014 pukul 19.53 WIB

${ }^{14}$ Terarsip dalam http://www.merdeka.com/politik/iklan-parpol-tak-signifikan-pengaruhi-pemilih.html diakses pada 9 Juli 2014 pukul 11.23 WIB
} 
dan SCTV. Sehingga besar potensi pemasangan iklan kampanye di channel lain yang bahkan tidak berada di bawah kepemilikan media tersebut.

Dari sini dapat kita ketahui jika terjadi dominasi yang sangat signifikan melalui komodifikasi konten di Indovison. Kondisi semacam ini sebelumnya digambarkan oleh McQuail dalam karakter dominasi media seperti berikut ${ }^{15}$ :

\begin{tabular}{|c|c|c|}
\hline & Dominasi & Pluralis \\
\hline Sumber masyarakat & $\begin{array}{l}\text { Kelas penguasa atau kelompok } \\
\text { elit dominan }\end{array}$ & $\begin{array}{l}\text { Berbagai kelompok politik, } \\
\text { sosial, dan budaya yang saling } \\
\text { bersaing }\end{array}$ \\
\hline Media & $\begin{array}{l}\text { Dimiliki oleh segelintir orang; } \\
\text { tipenya seragam }\end{array}$ & $\begin{array}{l}\text { Banyak dan independen satu } \\
\text { sama lain }\end{array}$ \\
\hline Produksi & $\begin{array}{l}\text { Distandarisasi, rutin, dan } \\
\text { dikontrol }\end{array}$ & kreatif, bebas, dan asli \\
\hline Isi dan cara pandang & $\begin{array}{l}\text { Selektif dan saling berkaitan; } \\
\text { ditentukan dari atas }\end{array}$ & $\begin{array}{l}\text { Berbagai pandangan dan saling } \\
\text { bersaing }\end{array}$ \\
\hline Khalayak & $\begin{array}{l}\text { Dependen, pasif, dan } \\
\text { diorganisasi dalam skala besar }\end{array}$ & $\begin{array}{l}\text { Terpisah-pisah, selektif, reaktif, } \\
\text { dan aktif }\end{array}$ \\
\hline Efek & $\begin{array}{l}\text { Besar; mempertegas tatanan } \\
\text { sosial yang sudah mapan }\end{array}$ & $\begin{array}{lcr}\text { Beraneka } & \text { ragam, } & \text { tidak } \\
\text { konsisten, } & \text { dan } & \text { tanpa } \\
\text { keteramalan } & \text { (prediktibilitas) } \\
\text { arah, tetapi } & \text { seringkali "tanpa } \\
\text { efek" } & & \end{array}$ \\
\hline
\end{tabular}

Cara memandang media dari model dominasi adalah bahwa media massa berkedudukan di bawah beberapa institusi lainnya sehingga independensinya terbatas. Berbagai organisasi media cenderung dikuasai segelintir orang kuat. Organisasi-organisasi media tersebut memiliki bentuk dan tujuannya yang sama. ${ }^{16}$ Model dominasi media juga dapat dimaknai bahwa tingkat produksi massal dan penyebaran pesan yang tinggi. Cara pandang model dominasi ini yang terbatas dan tidak bervariasi. Penataan media massa dalam model ini juga cenderung sesuai dengan perspektif penguasa media tersebut. instrumen-instrumen perspektif penguasa itulah yang kemudian disajikan kepada masyarakat. ${ }^{17}$ Dapat dikatakan jika dominasi yang menyelimuti media akan berimbas pada konten pesan yang dikonsumsi masyarakat. Sehingga apabila masyarakat mengonsumsi konten tersebut, jika tidak dibarengi dengan literasi media yang baik besar kemungkinan masyarakat akan mengonsumsi pesan yang telah dikontsruksi berdasar kepentingan pemilik media.

Komodifikasi yang terjadi di Indovision sendiri tumbuh beriringan dengan dominasi media yang ada. Sedangkan inti dari efek proses komodifikasi sendiri menurut Lessig yang dikutip oleh Hasan menunjukkan bahwa: 1) prosesnya tidak memakan ruang atau tidak mengikat budaya; dan 2)

\footnotetext{
${ }^{15}$ Dennis McQuail. 1996. Teori Komunikasi Massa. Erlangga: Jakarta. Hal. 82

16 Ibid.

17 Ardian Bakhtiar Rivai. 2014. Aburizal Bakrie: Dominasi Iklan Politik \&Perilaku Pemilih Pemula di Kota Yogyakarta.Tesis Magister Program Studi Ilmu Komunikasi UGM Yogyakarta. Hal.30-31
} 
menyebar secara lebih luas dan mendalam dengan tampilan yang natural. ${ }^{18}$ Dari pernyataan ini dapat disimpulkan jika proses komodifikasi berjalan seolah-olah tidak merubah budaya asli yang telah mengalami komodifikasi. Tampilan budaya massa hasil komodifikasi yang tampak natural membuat orang dengan mudah menerima tanpa ada penilaian kritis. ${ }^{19}$ Proses komodifikasi khalayak dirasakan hanya sebatas suatu kewajaran bagi institusi media mengingat TV berlangganan yang profit utama berasal dari khalayak. Sedangkan komodifikasi konten dari TV berlangganan sendiri memang menjadi landasan utama TV berlangganan untuk dapat terus hadir di tengah khalayak. Semua proses ini berjalan mulus hingga tidak disadari adanya motif-motif terselubung yang menghinggapi hamper di setiap konten spot iklan pada channel yang ada.

Hasil dari komodifikasi yang dilakukan Indovision di sini memang bertujuan untuk mencapai pemenuhan kepentingan politik sang pemilik. Dimana melalui media, opini publik digiring pada ideologi pemilik media. Zaller dan Mutz pun menguatkan jika media berpengaruh pada dinamika perubahan opini publik yang kemudian berdampak juga bagi perilaku politik. ${ }^{20}$

Karl Marx menyatakan bahwa kelas yang menguasai sarana produksi metarial juga memegang kontrol atas produksi mental. ${ }^{21}$ Oleh karena itu, secara umum dapat dikatakan bahwa wawasan orang yang tidak memiliki sarana produksi mental pun ikut dipengaruhi. Sehingga, mereka memerintah sebagai suatu kelas dan menentukan serta mewarnai babakan zaman. Sudah jelas, mereka pun mengatur produksi dan distribusi gagasan pada zamannya. Dengan demikian, gagasan mereka merupakan penguasa pada zamannya. Media memiliki pengaruh besar terhadap perubahan opini publik dan perilaku politik masyarakat karena adanya penanaman kognisi yang berasal dari media massa. Sehingga opini publik yang seharusnya bergerak dengan bebas pada akhirnya dapat terkungkung oleh media yang secara 'halus' menggenggam melalui komodifikasi khalayak dan konten yang telah ditanam sejak awal.

\section{PENUTUP}

TV satelit berlangganan hadir di tengah masyarakat sebagai pemenuh kebutuhan masyarakat atas hiburan dan informasi. Namun, kapitalisme yang mendasari terbentuknya suatu institusi media tidak dapat lepas dari tujuan pencapaian profit. Profit TV satelit berlangganan digapai melalui komodifikasi konten dan khalayak. Maksimalisasi komodifikasi konten menghadirkan saluran-saluran media penyiaran baru untuk memenuhi kebutuhan masyarakat.

\footnotetext{
${ }^{18}$ Hasan (2008) dalam Sumantri Raharjo. 2011. Komodifikasi Budaya Lokal dalam Televisi (Studi Wacana Kritis Komodifikasi Pangkur Jenggleng TVRI Yogyakarta). Tesis Magister Program Studi Ilmu Komunikasi. Surakarta: Universitas Sebelas Maret. hal. 22

${ }^{19}$ Sumantri Raharjo (2011).Ibid

${ }^{20}$ Setmeko (2007) dalam Ardian Bakhtiar Rivai. 2014. Aburizal Bakrie: Dominasi Iklan Politik \&Perilaku Pemilih Pemula di Kota Yogyakarta.Tesis Magister Program Studi Ilmu Komunikasi UGM Yogyakarta. Hal.9

${ }^{21}$ Dalam Ardian Bakhtiar Rivai (2014). Ibid. Hal. 28
} 
Komodifikasi khalayak dan komodifikasi konten yang terus dimaksimalkan oleh Indovision menjadi lahan potensial bagi sang pemilik media untuk berkampanye. Di sini spot-spot iklan dalam channel yang disediakan Indovision dikomodifikasi untuk iklan partai politik yang mengusungnya pada momentum pemilihan legislatif dan pemilihan presiden 2014. Pemilik media untuk mengendalikan konten siaran atas seluruh media yang ia miliki. Fenomena TV satelit berlangganan Indovision di sini memaparkan adanya transformasi historis yang mana kekuatan kepemilikan media secara dinamis berperan dalam pertumbuhan dan perubahan kapitalisme.

Fungsi media yang pada awalnya hadir sebagai pemenuh kebutuhan masyarakat atas hiburan kian bergeser dengan adanya upaya kapitalis untuk meningkatkan pangsa pelanggan setinggi mungkin. Dan kian bergeser lagi melihat media pada akhirnya dimanfaatkan untuk kepentingan politik sang pemilik media, yang mana dalam hal ini diberdayakan untuk kampanye pemilu presiden. Selain itu dimana media seharusnya secara berimbang memberi tayangan, khususnya politik, pada akhirnya terkungkung pada prinsip ekonomi yang mengharuskan konten dikonstruksi berdasar kepentingan "sang pemilik".

\section{DAFTAR PUSTAKA}

Alexander, Alison (et.al.). 2004. Media Economics: Theory and Practice $3^{\text {rd }}$ Ed. New Jersey: Lawrence Erlbaum Associates.

McQuail, Dennis. 1996. Teori Komunikasi Massa. Erlangga: Jakarta.

Mosco, Vincent. 2009. The Political Economy of Communication $2^{\text {nd }}$ Ed. London: SAGE Publication. Pribadi, Aditya Wahyu. 2012. Analisis Strategi Bersaing Dalam Rangka Kompetisi Industri TV Berlangganan (Studi Kasus: PT. Mediatama Anugrah Citra). Tesis Fakultas Teknik Magister Manajemen Telekomunikasi. Jakarta: Universitas Indonesia.

Raharjo, Sumantri. 2011. Komodifikasi Budaya Lokal dalam Televisi (Studi Wacana Kritis Komodifikasi Pangkur Jenggleng TVRI Yogyakarta). Tesis Magister Program Studi Ilmu Komunikasi. Surakarta: Universitas Sebelas Maret.

Retnowati, Yunu. 2013. Efektivitas Iklan dalam Meraih Prestasi Politik. Terasip dalam http://www.academia.edu/5498153/EFEKTIVITAS_IKLAN_DALAM_MERAIH_PARTISI PASI_POLITIK

Rivai, Ardian Bakhtiar. 2014. Aburizal Bakrie: Dominasi Iklan Politik \&Perilaku Pemilih Pemula di Kota Yogyakarta.Tesis Magister Program Studi Ilmu Komunikasi UGM Yogyakarta.

Sugiyono. 2012. Metode Penelitian Kuantitatif, Kualitatif dan R \& D. Bandung: Alfabeta.

Sukmadinata, Nana Syaodih. 2011. Metode Penelitian Pendidikan. Bandung: PT Remaja Rosdakarya. Website:

BERITASATU.com. 2013. Perkuat Pasar, MNC Sky Raih 1,86 Juta Pelanggan. Terarsip http://www.beritasatu.com/emiten/115230-perkuat-pasar-mnc-sky-raih-186-jutapelanggan.html 
DGspeak.com. 2013. Berkenalan Dengan TV Berlanggan. Terarsip dalam http://www.dgspeak.com/teknologi/berkenalan-dengan-tv-berlangganan/

Infotelevisi.com. 2014. MNC Vision. Terarsip dalam http://www.infotelevisi.com/1/tv-berlanggananIndovision/

Jpnn.com. 2014. Empat Parpol Langgar Aturan Iklan di TV. Terarsip dalam http://www.jpnn.com/read/2014/03/28/224951/Empat-Parpol-Langgar-Aturan-Iklan-di-TV-

Kontan.co.id. 2013. Indovison menggenggam 1,92 juta pelanggan. Terarsip dalam http://industri.kontan.co.id/news/indovision-menggenggam-192-juta-pelanggan

Merdeka.com. 2014. Iklan parpol tak signifikan pengaruhi pemilih. Terarsip dalam http://www.merdeka.com/politik/iklan-parpol-tak-signifikan-pengaruhi-pemilih.html 